\title{
4 輪車自動駐車システムの開発一理論と実験—
}

\author{
ダオミン クアン*・劉康 志*·大 形 明 弘* \\ Development of Auto-Parking System for 4-Wheeled Automobiles: Theory and Experiments \\ Dao Minh Quan*, Kang-Zhi LiU* and Akihiro OGata*
}

\begin{abstract}
The control of position and orientation angle of 4-wheeled cars is the central part in the development of automatic parking systems which is going to play an important role in ITS. There have been many approaches to this problem from a viewpoint of application of nonholonomic control theory. But there are still some practical problems such as steering angle limitation that need to be addressed. In this paper, a method is proposed to deal with the steering control with a steering angle limitation. The basic idea is to contruct a circle family and let the car approach the circle family that leads to the destination asymptotically. Both theoretical and experimental results are described.
\end{abstract}

Key Words: 4-wheeled car, auto-parking system, steering angle limitation, circle family

\section{1.はじめに}

自動車技術と IT 技術の進歩につれて，自動車の車間距離 制御, 隊列走行制御, ABS など自動運転システムは現実に なりつつある.しかし，その中で難しいといわれている自動 駐車制御にはまださまざまな問題が残っている．自動駐車制 御技術は将来 ITS(知能化交通システム)においては重要な 要素技術の一つである.

近年， 4 輪車の自動駐車制御問題は非ホロノミックシステ ムの一例としてよく取り上げられている. 非ホロノミックシ

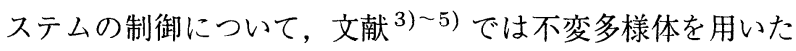
方法を提案した。 ${ }^{6)}$ では正準系への変換をせずに，バックス テッピング法でシステムを安定化する. ${ }^{7)}$ では可変拘束制御 を提案した. しかし, これらの研究で提案された方法では実 用上避けることのできない操舵角の限界, 駐車空間の制限 などの問題を解決できていないため，また実用化に至ってい ない.

完全自動化した駐車システムを実現するには, 操舵角と 駐車空間の制約を陽に考慮でき, かつ簡単な方法が必要で ある. そこで, 本研究では車両の操舵角の制限を考慮した, 比較的に簡単な駐車制御方法を提案する. 制御則の基本方策

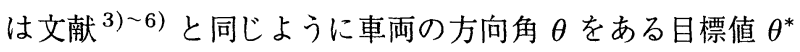
の集合(注1) 収束させることである。ただしこれらの文献 と違い, $\theta^{*}$ を求めていくのではなく, 文献 ${ }^{8)}$ で導入された

\section{* 千葉大学工学部学部 自然科学研究科}

* Faculty of Engineering, University of Chiba, 1-33 Yayoi-cho, Inage-ku, Chiba

(注 1）文献 3) -5) では不変多様体と呼ぶ, 文献 6) では仮想入力 と呼ぶ

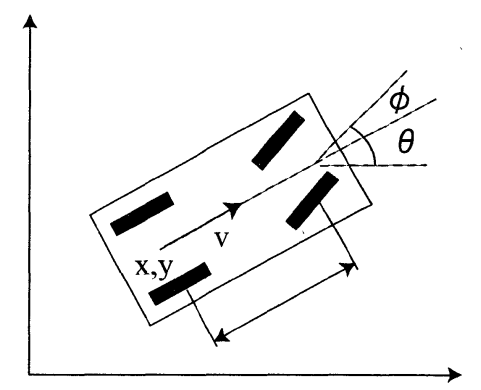

Fig. 1 Rear drive 4-wheel car model

円周族の接線方向を目標值 $\theta^{*}$ としている．また，本方法で は車両を前進後進に適切に切り替えることで, 操舵角とス ペースの制約の範囲内で駐車することができる.

本稿の前半では制御則について述べ, 後半では自動駐車シ ステムの実験結果を示す.なお，以下では $\operatorname{sgn}(x)$ で変数 $x$ の符号を表わす。

\section{2. 制御モデル}

本研究の制御モデルは Fig. 1 に示される後輪駆動 4 輪車 モデルである．車輪に横滑りが生じないと仮定すると車両の 運動学モデル(注 2) はつぎのように与えられる.

$$
\dot{x}=\cos \theta v
$$

（注 2）このモデルにおける速度 $v$ は車両方向に沿った速度であ る. 後輪駆動の場合 $v$ は後輪速度と同じで, 前輪駆動の場合 $v$ は前輪速度かける $\cos \phi$ となる。 またこのモデルを 4 輪車に適 用するとき, 内外輪の速度の差ならびに操舵角の差を考慮する 必要がある。 


$$
\begin{aligned}
& \dot{y}=\sin \theta v \\
& \dot{\theta}=\frac{1}{l} \tan \phi v
\end{aligned}
$$

ここで, $l$ は前後輪の車軸間の距離, $(x, y)$ は後輪車軸の中 央座標, $\theta$ は $x$ 軸に対する車両の方向角を表わす。 また， $\phi$ は操舵角, $v$ は車両の進行速度を表わす. 本稿では, 操舵角 $\phi$ の関数

$$
\eta=\tan \phi
$$

と進行速度 $v$ を入力として扱う. 通常, 非ホロノミックシ ステムの研究では操舵角速度 $\dot{\phi}$ を入力として扱うが, 操舵 角の制限を考慮することができない。よって, 本稿では操舵 角を直接制御入力として捉える.

ここで，状態ベクトル $z$ と制御入力 $u$ をそれぞれ

$$
\boldsymbol{z}=(x, y, \theta)^{T}, \quad \boldsymbol{u}=(v, v \eta)^{T}
$$

とおくと，状態方程式はつぎのように書ける。

$$
\dot{\boldsymbol{z}}=g(\boldsymbol{z}) \boldsymbol{u}, \quad g(\boldsymbol{z})=\left[\begin{array}{cc}
\cos \theta & 0 \\
\sin \theta & 0 \\
0 & 1 / l
\end{array}\right]
$$

制御の目的は状態 $z$ を原点

$$
\boldsymbol{z}=(x, y, \theta)^{T}=(0,0,0)^{T}
$$

へ収束させ，すなわち $z$ を安定化することである.

\section{3. 制御入力の設計と安定性の解析}

本節の前半では, 操舵角に制限がないと仮定して制御入力 を設計し，後半では操舵角制限がある場合の対策を提案す

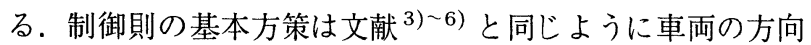
$\theta$ をある目標値 $\theta^{*}$ の集合へ収束させることである. 3.1 節 では目標値 $\theta^{*}$ の集合について述べる. 3.2 節では車両の方 向 $\theta$ が $\theta^{*}$ になったとき, その状態を維持するための入力に 関する条件を導出する. 3.3 節では車両の位置から原点まで の距離が常に減少するための条件を求める．以上の結果に 基づいて, 3.4 節では操舵角に制限がないと仮定して制御器 を設計する. 3.5 節では操舵角の制限を考慮して, 制御入力 を修正する. そして, システムを安定化できるための初期值 に関する条件を求める. 最後に 3.6 節では車両の状態が 3.3 節と 3.5 節で求めた条件を満たさないときの方策について 述べる。

\section{1 円周族}

Fig. 2 に示す円集合

$$
\left\{(x, y): x^{2}+(y-r)^{2}=r, r \in(0, \infty)\right\}
$$

を円周族と呼ぶ.これらの円は半径 $r$ をも , 中心点が $\mathrm{y}$ 軸上にあり, 原点で $x$ 軸と接する． $\theta^{*}$ を円軌道の接線方向 角とし， $\delta$ を極座標系に扔ける点 $(x, y)$ の角度とすると, 原 点以外ではつぎの関係が成り立つ.

$$
\theta^{*}=2 \delta
$$

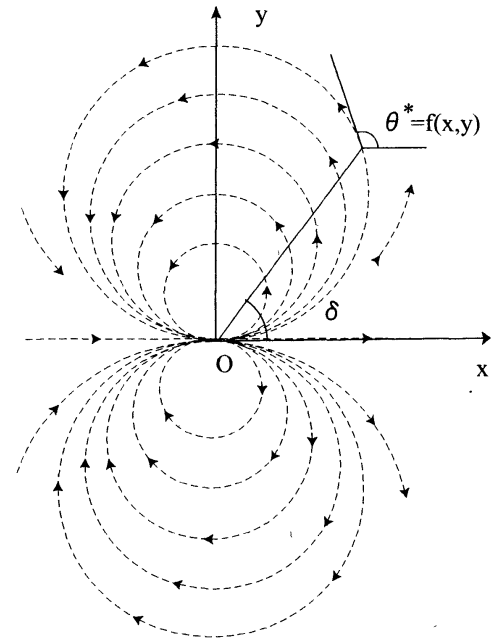

Fig. 2 Circle family

ただし，反はつぎのように定義される。

$$
\delta= \begin{cases}\arctan \frac{y}{x}, & (x, y) \neq(0,0) \\ 0, & (x, y)=(0,0)\end{cases}
$$

Fig. 2 よりわかるように，4 輪車が円周族に沿って動けば, 必ず原点に到達できる。そこで; $\theta^{*} を \theta$ の目標值とする。 以下 $\theta^{*}$ の性質を調べておく.

$\delta$ の範囲を $[-\pi / 2, \pi / 2]$ とする: すなわち，4 輪車を第 1 , 4 象限に拘束するとする.このとき，Fig. 2 および

$$
|\delta| \leq \frac{\pi}{2}
$$

より

$$
\begin{aligned}
& \frac{x}{\sqrt{x^{2}+y^{2}}}=\operatorname{sgn}(x) \cos \delta \\
& \frac{y}{\sqrt{x^{2}+y^{2}}}=\operatorname{sgn}(x) \sin \delta
\end{aligned}
$$

が成立つ. 車両を第 2,3 象限に拘束する場合は同様に $\delta$ を 定義できるので, 省略する。また, 方向角の誤差を

$$
e=\theta-\theta^{*}
$$

とおくと，つぎの関係が成立つ.

$$
\theta-\delta=e+\delta
$$

ここで, $\dot{\delta}$ を求めておこう.

$$
\begin{aligned}
\dot{\delta} & =\frac{d}{d t}\left(\arctan \frac{y}{x}\right)=\cos ^{2} \delta \frac{\dot{y} x-\dot{x} y}{x^{2}} \\
& =\frac{x^{2}}{x^{2}+y^{2}} \frac{x \sin \theta v-y \cos \theta v}{x^{2}} \\
& =\frac{x \sin \theta v-y \cos \theta v}{x^{2}+y^{2}}
\end{aligned}
$$

さらに，(9)，(10) および (12)を用いると上式は

$$
\dot{\delta}=\operatorname{sgn}(x) \frac{\sin (e+\delta)}{\sqrt{x^{2}+y^{2}}} v
$$


となる。

文献 ${ }^{8)}$ は以下の点において本稿と異なる。まず，文献 ${ }^{8)}$ では円周族に沿って車両の位置から原点までの円弧の長さと 車両の方向と円周族の接線方向との角度誤差を収束させる. そのため, システムを線形化し, 線形理論でシステムの安定 性を考えている。そして，2 輪車両を制御対象とするので， 操舵角の制限がない。さらに，空間の制限を考慮していな い.これに対し，本研究ではシステムを線形化せずに，不変 多様体を用いて車両の位置から原点までの距離と車両の方 向と円周族の接線方向との角度誤差を収束させる.さらに, 4 輪車の駐車システムを考えるので，操舵角の制限，空間の 制限を考慮する。

\section{2 拘束条件の導出}

本稿の制御則は $\theta$ を $\theta^{*}$ 一収束させることによって状態の 安定化を図るので, $\theta=\theta^{*}$, すなわち $\theta-2 \arctan (y / x)=0$ になったとき，その状態を維持しなければならない。こ こではシステム $\dot{\boldsymbol{z}}=f(\boldsymbol{z})=g(\boldsymbol{z}) u$ の状態を多様体 $h(\boldsymbol{z})=\theta-2 \arctan (y / x)=0$ に拘束する条件を求める.

システムの状態を多様体に拘束したとき， $h(z)$. 00 が成 り立つ.したがって条件

$$
L_{f} h(\boldsymbol{z})=\frac{\partial h}{\partial \boldsymbol{z}} f=\frac{\partial h}{\partial \boldsymbol{z}} \dot{\boldsymbol{z}}=\dot{h}=0
$$

が成立しなければならない。ここで，

$$
\frac{\partial h}{\partial \boldsymbol{z}}=\left[\frac{2 y}{x^{2}+y^{2}},-\frac{2 x}{x^{2}+y^{2}}, 1\right]
$$

を

$$
L_{f} h(\boldsymbol{z})=\frac{\partial h}{\partial \boldsymbol{z}} g(\boldsymbol{z}) \boldsymbol{u}
$$

に代入して計算すると

$$
\begin{aligned}
L_{f} h(\boldsymbol{z}) & =\left[\frac{2 y}{x^{2}+y^{2}} \cos \theta-\frac{2 x}{x^{2}+y^{2}} \sin \theta, \frac{1}{l}\right]\left[\begin{array}{c}
v \\
v \eta
\end{array}\right] \\
& =\left(\frac{2 y}{x^{2}+y^{2}} \cos \theta-\frac{2 x}{x^{2}+y^{2}} \sin \theta+\frac{1}{l} \eta\right) v
\end{aligned}
$$

となる，さらに，(9), (10) および $(12)$ を用いると

$$
L_{f} h(\boldsymbol{z})=\left(-\operatorname{sgn}(x) \frac{2 \sin (e+\delta)}{\sqrt{x^{2}+y^{2}}}+\frac{1}{l} \eta\right) v
$$

と書ける. したがって, システム (4)を多様体 $h(\boldsymbol{z})=0, つ$ まり $\theta=\theta^{*}$ に拘束するには，操舵角は以下の条件を満たさ なければならないことがわかる.

[補題 1] 4 輪車の方向角 $\theta$ を円周族の接線方向 $\theta^{*}$ に 拘束するために, 操舵角は $\eta=\eta_{\text {ref }}$ でなければならな い.ただ

$$
\eta_{r e f} \triangleq \operatorname{sgn}(x) \frac{2 l \sin \delta}{\sqrt{x^{2}+y^{2}}}
$$

である。

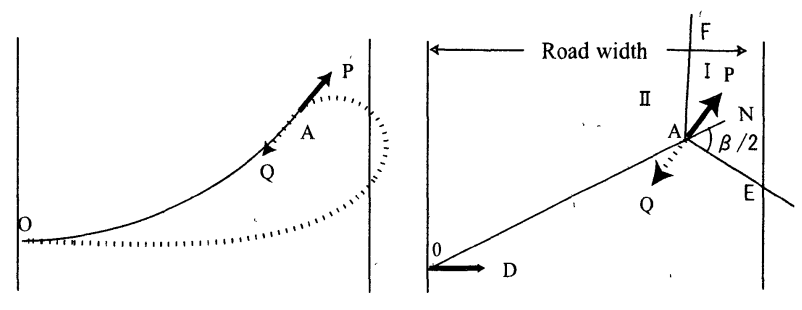

Fig. 3 parking setup

\section{3 駐車問題の設定}

ここで，駐車問題を設定する. Fig. 3 の右図に注目され たい. 点 $A$ は車両のスタートする位置, 点 $O$ は目的地, 矢 印 $(\overrightarrow{A P}$ あいは $\overrightarrow{A Q})$ は車両の方向 $\theta$ を表わす，通路の幅の 範囲内で車両を目的地 $\mathrm{O}$ まで動かしたい.

$A E, A F$ それぞれが $O A$ と $\beta / 2(\beta<\pi)$ の角度をなす とする。このとき， $E A F$ は駐車空間を二つの領域 I と II に分ける. $\angle A O D=\delta$ なので，車両の方向が領域 I にある とき，

$$
|\theta-\delta|<\frac{\beta}{2}, \quad \beta<\pi
$$

となり (図では $\angle P A N<\beta / 2$ )，また領域 II にあるとき

$$
|\theta-\delta| \geq \frac{\beta}{2}
$$

となる(図では $\angle N A Q>\beta / 2)$. 例として，車両を後進させ て目的地へ動かすことを考える，車両の方向が領域 I にあっ た場合 (実線矢印 $\overrightarrow{A P}$ ) は Fig. 3 の左図の実線ように車両の 位置から目的地までの距離を常に減少させることができる. 一方，車両の方向が領域 II にあった場合 (点線矢印 $\overrightarrow{A Q}$ ) は Fig. 3 の左図の破線のように車両の位置から目的地までの距 離が一時的に増加し，車両の軌道を膨らませるので，通路か らはみ出る可能性がある．以降，車両の方向が領域 Iにある と仮定して制御入力を設計する，なお，領域 II にあった場 合については 3.6 節で述べる。

$|e+\delta|$ はつぎの性質をもち, フィードバック制御則の安 定性を示すときに用いられる。

[補題 2］車両の進行速度 $v$ は

$$
\left\{\begin{array}{cc}
y=0 & x=y=0 \\
\operatorname{sgn}(x) v<0 & x, y \neq 0
\end{array}\right.
$$

を満たし，方向角誤差の絶対值 $|e|$ は減少関数である

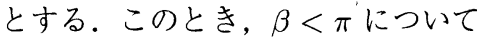

$$
|\theta(0)-\delta(0)|=|e(0)+\delta(0)| \leq \frac{\beta}{2},|\delta(0)| \leq \frac{\beta}{2}
$$

が成り立てば，すべての時刻において

$$
|\theta(t)-\delta(t)|=|e(t)+\delta(t)| \leq \frac{\beta}{2}, t \geq 0
$$

が成り立つ。

証明： 証明の中で以下の性質を用いる。 $p, q$ を時間炕 関する一階連続微分可能関数とする. 
( 1 ),$|q|<\pi \Rightarrow \operatorname{sgn}(\sin (q))=\operatorname{sgn}(q)$

(2) (a) $\operatorname{sgn}(p)=\operatorname{sgn}(q)$ ならば, $\operatorname{sgn}(p \sin (p+q))=1$.

(b) $\operatorname{sgn}(p)=-\operatorname{sgn}(q)$ かつ $|q|<|p|$ ならば, $\operatorname{sgn}(p$ $\sin (p+q))=1$.

(3) $|p|$ と $|q|$ は減少関数で, $\operatorname{sgn}(p)=\operatorname{sgn}(q)$ ならば, $|p+q|$ も減少関数である.

これらの性質は明らかであるので，証明を省く，以上の性質 を用いて, 補題 2 を示す.ここで

$$
U(\delta)=\frac{1}{2} \delta^{2}
$$

とする. (13) 式を用いて $\dot{U}(\delta)$ を計算すると

$$
\dot{U}(\delta)=\delta \dot{\delta}=\operatorname{sgn}(x) v \frac{\delta \sin (e+\delta)}{\sqrt{x^{2}+y^{2}}}
$$

条件 $\operatorname{sgn}(x) v<0$ より $\dot{U}(\delta)$ の符号は $-\delta \sin (e+\delta)$ の符 号となる.すなわち,

$$
\operatorname{sgn}(\dot{U}(\delta))=-\operatorname{sgn}(\delta \sin (e+\delta))
$$

である. 以下, $e$ と $\delta$ の符号と大小関係について三つのヶー スに分けて補題を示す。

case 1: $\operatorname{sgn}(e(t))=\operatorname{sgn}(\delta(t))$

性質 $(2)$ の $(\mathrm{a})$ より $\operatorname{sgn}(\dot{U}(\delta))=-1<0$. このとき, $|\delta|$ は減少関数となる.さらに, $|e|$ が減少関数である仮定から, 性質 $(3)$ より $|e+\delta|$ も減少関数となる.

case 2: $\operatorname{sgn}(e(t))=-\operatorname{sgn}(\delta(t))$, かつ $|\delta(t)|<|e(t)|$ まず，仮定から

$$
\operatorname{sgn}(e+\delta)=\operatorname{sgn}(e)=-\operatorname{sgn}(\delta)
$$

が成り立つ。って

$$
\operatorname{sgn}(\dot{U}(\delta))=-\operatorname{sgn}(\delta \sin (e+\delta))=1
$$

となり， $|\delta|$ が増加関数となる：また， case 2 の仮定から

$$
|e(t)+\delta(t)|=|e(t)|-|\delta(t)|
$$

がいえる. $|\delta|$ が増加関数, $|e|$ が減少関数であることから上 式の関数は減少する.

case 3: $\operatorname{sgn}(e(t))=-\operatorname{sgn}(\delta(t))$, かつ $|\delta(t)|>|e(t)|$ 性質 (2) の (b)より

$$
\operatorname{sgn}(\dot{U}(\delta))=-\operatorname{sgn}(\delta \sin (e+\delta))=-1<0
$$

となる.よって, $|\delta|$ が減少関数である。ささに, case 3 の 仮定により

$$
|e(t)+\delta(t)|=|\delta(t)|-|e(t)| \leq|\delta(t)| \leq|\delta(0)|
$$

が成り立つ。さらに, $|\delta(0)|<\beta / 2$ の条件から

$$
|e(t)+\delta(t)|<\frac{\beta}{2}
$$

がいえる．以上のことより結論が得られる。

\section{4 制御入力の設計}

方向角誤差 $e=\theta-\theta^{*}=\theta-2 \delta$ および (13) を用いて 4 輪車モデルを書き直すと

$$
\dot{x}=\cos (e+2 \delta) v
$$

$$
\begin{aligned}
& \dot{y}=\sin (e+2 \delta) v \\
& \dot{e}=\left(\frac{1}{l} \eta-\frac{2 \operatorname{sgn}(x) \sin (e+\delta)}{\sqrt{x^{2}+y^{2}}}\right) v
\end{aligned}
$$

となる．ただし， $\eta, v$ は制御入力である。また，車両の原点 までの距離を

$$
r(t)=\sqrt{x^{2}+y^{2}}
$$

で表わし，軌道に沿った車両の移動距離を

$$
s(t)=\int_{0}^{t}|v(\tau)| d \tau
$$

で表わす.

《定理 1》つぎの信号を定義しておく

$$
\eta^{*} \triangleq \operatorname{sgn}(x) \frac{2 l \sin (e+\delta)}{r}-\alpha l e \operatorname{sgn}(v), \alpha>0
$$

操舵角に制限がないとする. 操舵角入力を $\eta=\eta^{*}$ と すると, 方向角誤差 $e$ は

$$
e(t)=\exp (-\alpha s(t)) e(0)
$$

のオーダーで収束する.ささらに, 進行速度 $v$ について は原点から遠いところでは $\operatorname{sgn}(x) v<0$ を満たすとし， 原点近傍では

$$
v=-\operatorname{sgn}(x) c r, \quad c>0
$$

とするとき, $\beta<\pi$ について

$$
|\theta(0)-\delta(0)|<\frac{\beta}{2}, \quad|\delta(0)|<\frac{\beta}{2}
$$

が成立てば，原点までの距離 $r$ は

$$
\exp (-c t) r(0) \leq r(t)<\exp (-c \cos (\beta / 2) t) r(0)(25)
$$

を満たし，指数的に収束する。

証明：まず，操舵角入力を (19) 式に代入したとき

$$
\dot{e}=-\alpha|v| e
$$

が成立つ，その応答を求めると，

$$
e(t)=\exp \left(-\alpha \int_{0}^{t}|v| d \tau\right) e(0)=\exp (-\alpha s(t)) e(0)
$$

を得る．車両の移動距離 $s(t)$ が長ければ， $e(t)$ を十分に低 減できる.

つぎに，軌道に沿って $r$ を微分し，(9)，(10) および (17), (18) を代入すると

$$
\begin{aligned}
\dot{r} & =\frac{x \dot{x}+y \dot{y}}{r} \\
& =\operatorname{sgn}(x)[\cos \delta \cos (e+2 \delta)+\sin \delta \sin (e+2 \delta)] v \\
& =\operatorname{sgn}(x) v \cos (e+\delta)
\end{aligned}
$$

が得られる。車両が与えられた初期状態からスタートする とき, 補題 1 より $|e+\delta|<\beta / 2$ が常に成り立つ. よって, $\cos (\beta / 2)<\cos (e+\delta) \leq 1$ である. $v=-\operatorname{sgn}(x) c r$ を代入 すれば

$$
-c r \leq \dot{r}<-c \cos (\beta / 2) r
$$


を得る．比較定理にしたがって計算すれば $(25)$ がわかる. よって，原点までの距離 $r$ は指数収束する.

\section{5 操舵角制限の考慮}

実車両の操舵角に制限があるので, 設計した操舵角が制限 を越えた場合, 安定性は保証できなくなる恐れがある. 本節 では設計した制御入力 $\eta^{*}$ が制限範囲を超えたときの安定性 の解析を行ない, 安定性を保証できるように制御入力 $\eta^{*}$ を 修正する。ここで, 車両の操舵角の制限を

$$
\eta \in\left[-\eta_{\max }, \eta_{\max }\right], \eta_{\max }>0
$$

と仮定し，制御入力 $\eta$ をつぎのように修正する。

$$
\eta= \begin{cases}\eta^{*}, & \left|\eta^{*}\right| \leq \eta_{\max } \\ \operatorname{sgn}\left(\eta^{*}\right) \eta_{\max }, & \left|\eta^{*}\right|>\eta_{\max }\end{cases}
$$

すなわち，設計した制御入力 $\eta^{*}$ が制限を越えたとき，操舵 角を飽和させる. 以下，(29) 式の制御入力で制御するとき， システムが安定になるかどうかについて調べる.

$\left|\eta^{*}\right| \leq \eta_{\max }$ のとき, 定理 1 より $x, y, \theta$ の収束性が保証 される.よって $\left|\eta^{*}\right| \geq \eta_{\max }$ の場合だけを考えればよい.さ らに，補題 1 よりわかるように方向角誤差 $e$ を零に拘束す るには操舵角入力が $(15)$ 式の $\eta_{r e f}(t)$ とならなければなら ない.ゆえに，飽和した操舵角入力ではほとんどすべての時 刻において $e(t) \neq 0$ である.

そこで, 以下では $e \neq 0$ とおく. $\operatorname{sgn}(x)=-\operatorname{sgn}(v)$ を用 いて (22) 式から $\alpha$ を計算すると, 形式的には $\alpha$ は

$$
\alpha=-\frac{1}{e l}\left(\frac{2 l \sin (e+\delta)}{r}+\operatorname{sgn}(v) \eta\right)
$$

と書ける. 入力 $\eta$ が飽和したとき, 上式の制御ゲイン $\alpha$ は 時変ゲイン $\alpha_{m}(t)$ に変わる。すなわち, $\eta=\operatorname{sgn}\left(\eta^{*}\right) \eta_{\max }$ を上式に代入したとき制御ゲインは

$$
\alpha_{m}(t)=-\frac{1}{e l}\left(\frac{2 l \sin (e+\delta)}{r}+\operatorname{sgn}(v) \operatorname{sgn}\left(\eta^{*}\right) \eta_{\max }\right)
$$

となる.この $\alpha_{m}$ は正である限り, 状態 $x, y$ の安定性と $\theta$ の収束性が保証される。そして,この条件は次式と等価で ある。

$$
\operatorname{sgn}(e)\left(\frac{2 l \sin (e+\delta)}{r}+\operatorname{sgn}(v) \operatorname{sgn}\left(\eta^{*}\right) \eta_{\max }\right)<0
$$

上式はさらにつぎのように変形できる.

$$
-\operatorname{sgn}(e) \operatorname{sgn}(v) \operatorname{sgn}\left(\eta^{*}\right) \eta_{\max }>Z(x, y, \theta)
$$
ただし，

$$
Z(x, y, \theta)=\operatorname{sgn}(e) \frac{2 l \sin (e+\delta)}{r}
$$

である.また, $\left|\eta^{*}\right|>\eta_{\max }$ の間, (32) 式の左辺は定数で ある。なぜなら，(22) 式から $\eta^{*}$ は連続関数であるので, $\left|\eta^{*}\right|>\eta_{\max }$ の間では $\operatorname{sgn}\left(\eta^{*}\right)$ は定数である. そして, 飽和 した入力を (19) 式に代入すると

$$
\begin{aligned}
& \dot{e}=-\alpha_{m}(t)|v(t)| e \\
& \Rightarrow e(t)=\exp \left(-\int_{0}^{t} \alpha_{m}|v| d \tau\right) e(0)
\end{aligned}
$$

となり, $e$ の符号は変化しない.さらに, 制御中 $\operatorname{sgn}(v)$ の 符号を変えないので, (32) 左辺は定数である. したがって, 初期時刻において $(32)$ 式が成り立ち, そして $Z(x, y, \theta)$ が 減少関数であれば，すべての時刻において (32) 式が成り立 つ.すなわち, システムを安定化できる.

以下, $Z(x, y, \theta)$ が減少関数であることを示す. $\dot{Z}$ を求め ると

$$
\begin{aligned}
\dot{Z}= & \frac{2 l \operatorname{sgn}(e) \cos (e+\delta)(\dot{e}+\dot{\delta})}{r} \\
& -\frac{2 l \operatorname{sgn}(e) \sin (e+\delta) \dot{r}}{r^{2}}
\end{aligned}
$$

となる. 上式に $(13),(26)$ と $\dot{e}=-\alpha_{m} e|v|, \operatorname{sgn}(x) v=-|v|$ を代入すると，

$$
\begin{aligned}
\dot{Z}= & -\frac{2 l \cos (e+\delta) \alpha_{m}(t)|e \|| v \mid}{r} \\
& -\frac{2 l \operatorname{sgn}(e) \cos (e+\delta) \sin (e+\delta)|v|}{r^{2}} \\
& +\frac{2 l \operatorname{sgn}(e) \sin (e+\delta) \cos (e+\delta)|v|}{r^{2}} \\
= & -\frac{2 l \alpha_{m}(t) \cos (e+\delta)|e||v|}{r}
\end{aligned}
$$

が得られる。また, 操舵角入力 $\eta$ が飽和しないとき, 上式 の時変ゲイン $\alpha_{m}(t)$ を定数ゲイン $\alpha$ に置き換えればそのま ま成り立つ。

初期時刻において $(32)$ 式が成り立てば, $\alpha_{m}(0)>0$ であ る. また, $|e(0)+\delta(0)|<\beta / 2<\pi / 2$ が成り立てば

$$
\cos (e(0)+\delta(0))>0
$$

が成り立つ.このとき, $\dot{Z}(0)<0$ となり, $Z$ は $t=0$ で減 少関数となる.したがって, つぎの時刻 $t=0_{+}$においても (32) 式が成り立ち, $\alpha_{m}\left(0_{+}\right)>0$ である. また, (34) 式と $\frac{d|e|}{d t}=\operatorname{sgn}(e) \dot{e}$ より $\frac{d|e|}{d t}=-\alpha_{m}(t)|v(t)||e|$ が成立.よって, $\frac{d|e(0)|}{d t}<0$, つまり, $|e|$ は $t=0$ で減少関数である.ささら に $|\delta(0)|<\beta / 2$ であれば, 補題 2 よりつぎの時刻 $t=0_{+}$ でも $|e+\delta|<\beta / 2$ となる.したがって,

$$
\cos \left(e\left(0_{+}\right)+\delta\left(0_{+}\right)\right)>0
$$

が成り立ち, $Z$ は $t=0_{+}$で減少関数である.この 議論を繰り返していけば, 初期時刻において (32) 式と $|e(0)+\delta(0)|<\beta / 2,|\delta(0)|<\beta / 2$ が成り立てば, すべ ての時刻において $Z$ は減少関数となることがわかる.つま り, 操舵角の制限の範囲内でシステムの状態を収束させるこ とができる，以上の議論より，つぎの定理が得られる.

《定理 2》 入力 $\eta$ の制限值を $\eta_{\max }$ とする. $\beta<\pi に$ วいて

$$
\begin{aligned}
& \quad|\theta(0)-\delta(0)|<\frac{\beta}{2}, \quad \delta(0)<\frac{\beta}{2} \\
& Z(x(0), y(0), \theta(0))<-\operatorname{sgn}(e) \operatorname{sgn}(v) \operatorname{sgn}\left(\eta^{*}\right) \eta_{\max } \\
& \text { が成り立つとき, }(24),(29) \text { 式の入力で }(x, y) \text { の安定 } \\
& \text { 性と } \theta \text { の収束性を保証できる. }
\end{aligned}
$$

次節では定理 2 の仮定が成り立ったない場合について述べる. 


\section{6 切り替え則}

まず，(32) 式の性質について調べる。ここで

$$
\eta_{\max }>\left|\frac{2 l \sin (e+\delta)}{r}\right|
$$

と仮定する. $\operatorname{sgn}(x)=-\operatorname{sgn}(v)$ を用いて $(22)$ を書き直すと

$$
\eta^{*}=-\operatorname{sgn}(v)\left(\frac{2 l \sin (e+\delta)}{r}+\alpha l e\right)
$$

となる．仮定 (35) と上式より， $\left|\eta^{*}\right|>\eta_{\max }$ の必要条件は

$$
\operatorname{sgn}(\sin (e+\delta))=\operatorname{sgn}(e)
$$

もしくは

$$
\left\{\begin{array}{l}
\operatorname{sgn}(\sin (e+\delta))=-\operatorname{sgn}(e) \\
|\alpha l e|>\left|\frac{2 l \sin (e+\delta)}{r}\right|+\eta_{\max }
\end{array}\right.
$$

である.いずれの場合でも, $2 l \sin (e+\delta) / r+\alpha l e$ の符号は $e$ と同じである。ゆえに

$$
\operatorname{sgn}\left(\eta^{*}\right)=-\operatorname{sgn}(v) \operatorname{sgn}(e)
$$

これを (32) 式に代入すると (32) 式は

$$
\eta_{\max }>\operatorname{sgn}(e) \frac{2 l \sin (e+\delta)}{r}
$$

となる. (35) 式が成り立てば, 上式も成り立つ。よって, 条 件 (32) は (35) に含まれる。さらに, (35) を変形すると

$$
r>\frac{2 l|\sin (e+\delta)|}{\eta_{\max }}
$$

の条件となる. $\sin$ 関数の絶対值が 1 以下であるから，条件 (35) はつぎの条件

$$
r>\frac{2 l}{\eta_{\max }}
$$

に含まれる．上式の左辺は車両の現在地から原点までの距離 であるので， $r$ が十分大きければ上式は成立する。したがっ て, $t=0$ で条件 (32) が成り立たない場合, 車両を原点か ら離れる方向へ直進させればよい.

つぎに, 初期角度の条件が成り立たないときの切り替え則 について説明する. Fig. 4 のように座標系 $O(x, y)$ を設定す ると, 条件 $|\delta(0)|<\beta / 2(<\pi / 2)$ は自動的に成立する. 一方, Fig. 3 からわかるように条件 $|e(0)+\delta(0)|<\beta / 2(<\pi / 2)$ が 成り立たない場合，駐車目的方向に対して車両が非常に不利 な方向にある、マニュアル運転するとき，車両がこのような 方向にある場合は駐車方向に対して入りやすい中間位置と 方向へ移動してから駐車を行なう。以下，このような中間位 置と方向を求める。

簡単のためにある目的位置と方向に対して，車両を安定化 可能の条件を

$$
\begin{aligned}
|e(0)+\delta(0)| & <\frac{\beta}{2}<\frac{\pi}{2} \\
r(0) & >\frac{2 l}{\eta_{\max }}
\end{aligned}
$$

とする. 条件 (39), (40) は定理 2 の条件を含めるので, 安 定性が保証される。

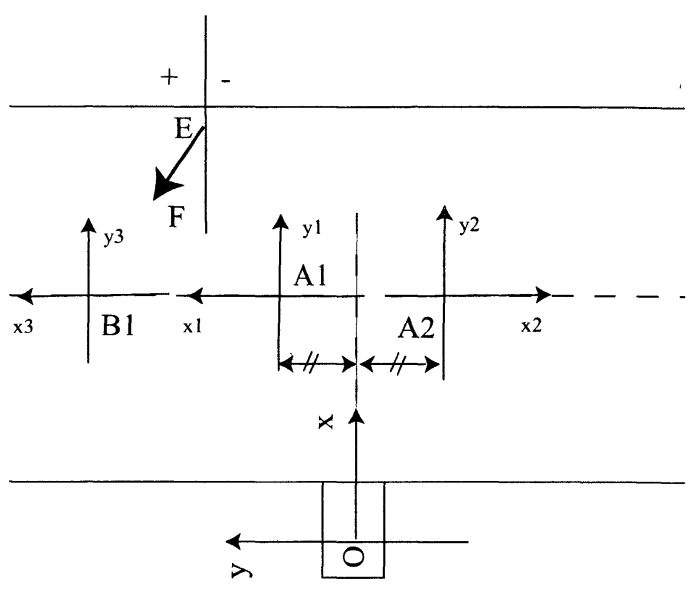

Fig. 4 The swiching rule

つぎに, Fig. 4 を用いて切り替え則を説明する. 以下では $y_{A 1}$ で座標系 $O(x, y)$ から見た点 $A 1$ の $y$ 座標を表わす.

$x_{A 1}$ なども同様である。点 $E$ と矢印 $\overrightarrow{E F}$ は車両の位置と 方向を表わす. 駐車位置と方向は原点 $O$ と座標系 $O(x, y)$ の $x$ 方向である. 座標系 $O(x, y)$ に対して車両の方向は条 件 $|e(0)+\delta(0)|<\beta / 2(<\pi / 2)$ を満たさないとする.この 場合, Fig. 4 のように通路の中心線上に

$$
\begin{aligned}
O A 2=O A 1 & =\frac{2 l}{\eta_{\max }} \\
y_{A 1} & =-y_{A 2}
\end{aligned}
$$

を満たす 2 点 $A 1, A 2$ および座標系 $A 1(x 1, y 1), A 2(x 2, y 2)$ を設定する。車両の位置と方向は各座標系 $A 1(x 1, y 1)$, $A 2(x 2, y 2)$ の原点と $x$ 軸方向にあったとき, 定理 2 の条件 が成り立つ.よって, 車両の位置と方向を座標系 $A 1(x 1, y 1)$ あるいは $A 2(x 2, y 2)$ の原点と $x$ 軸へ移動させて, そしてそ こから駐車スペースに入ればよい. 制御の手順はつぎのよう になる。

step 1 車両の位置と方向を座標系 $A 1(x 1, y 1)$ へ移動す るか座標系 $A 2(x 2, y 2)$ へ移動するかを決める. Fig. 4 の ように車両の方向を通路の垂直方向と比較して, “十”側に あれば $A 1(x 1, y 1)$, “_”側にあれば座標系 $A 2(x 2, y 2)$ へ移動する。すなわち，

$$
\operatorname{sgn}(\pi-\theta)=\left\{\begin{array}{cl}
1 & \rightarrow A 1 \\
-1 & \rightarrow A 2 へ
\end{array}\right.
$$

たとえば，Fig. 4 の場合は $A 1(x 1, y 1)$ へ移動することに なる，以下これを例につぎのステップを説明する。

step 2 座標系 $A 1(x 1, y 1)$ に対して条件 (39), (40) が成 り立つかどうかを確認する，成り立つ場合は (24), (29) で設計した入力で座標系 $A 1(x 1, y 1), O(x, y)$ へ順番に移 動させる。

step 3 step2で条件 (39), (40) が成り立たない場合は原 点 $A 1$ から $x 1$ 軸の正の側に定理 2 の条件が成り立つよう 
な座標系 $B 1(x 3, y 3)$ を決める。(24)，(29) で設計した入 力で座標系 $B 1(x 3, y 3), A 1(x 1, y 1), O(x, y)$ 一順番に移 動させる. $B 1$ の決め方は条件 (39), (40) から二つの代数 方程式を解くことによって簡単に求められる。たとえば

$$
\begin{aligned}
& x_{B 1}=x_{A 1} \\
& y_{B 1}= \begin{cases}y+\sqrt{\frac{2 l}{\eta_{\text {max. }}}}, & y \geq 0 \\
y-\sqrt{\frac{2 l}{\eta_{\text {max }}}}, & y \leq 0\end{cases}
\end{aligned}
$$

とすればよい

\section{4. 前輪駆動 4 輪車}

前輪駆動 4 輪車の運動学方程式は次式で与えられる。

$$
\begin{aligned}
\dot{x} & =\cos \theta \cos \phi u \\
\dot{y} & =\sin \theta \cos \phi u \\
\dot{\theta} & =\frac{1}{l} \sin \phi u
\end{aligned}
$$

操舵角に制限を持たせているので， $|\phi|<\pi / 2$ から $\cos \phi \neq 0$ である.よって, $v=u / \cos \phi$ とおけば, 後輪駆動 4 輪車シ ステムに帰着させることができる。すなわち，本研究の制御 手法は前輪駆動 4 輪車にも適用できる.

\section{5. 制 御 実 験}

本節では駐車制御実験の結果を示す．実験装置は Fig. 5 の後輪駆動 4 輪車である. 上部は通信用のノートパソコン で，モニタープログラムの通信とポジションセンサーから の情報を車両に搭載される $8086 \mathrm{CPU}$ へ伝送する。下部は Japannese System Design 社が製作した後輪駆動 4 輪車で ある、後輪部の車輪の左右はそれぞれのモー夕で動かされる。 各車輪に回転速度を測定するエンコーダーがついている．前 輪の操舵角も別々のモー夕により制御される．操舵角は角度 センサーにより測定される。ここで, 操舵角に $-45^{\circ} \sim 45^{\circ}$ の制限を加えている．また，車両の両端に発光ダイオードを つけ，天井に設置されるポジションセンサーカメラにより車 両の位置と方向を測定する，車幅は $22[\mathrm{~cm}]$, 長さは $20[\mathrm{~cm}]$ である，車両に搭載するハードウエアの制約上，駆動輪であ る後輪には $0, \pm 1, \cdots \pm 16$ の 33 通りの整数でしか入力でき ない. 駆動輪である後輪への入力は整数でしか実現できな

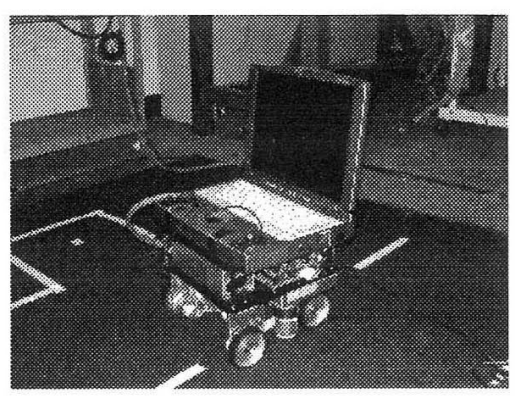

Fig. 5 Experimental vehicle

い.また，車両の方向角は二つのダイオードの位置から計算
されるので，車両が原点に近づくとき，位置情報の誤差によ る影響は非常に大きい. 操舵角 $\phi$ のループは PDで制御さ れ，設計した $\phi$ は目標值として入力される．Fig. 5 の 4 輪 車を用いて 3 節で設計した制御入力でバック駐車, 斜め駐 車の制御実験を行なった。前進駐車と駐車位置から車両を取 り出す動作などは基本的に同じ方法で実現できる.

\section{1 バック駐車}

まず，バック駐車制御実験について述べる。通常駐車す

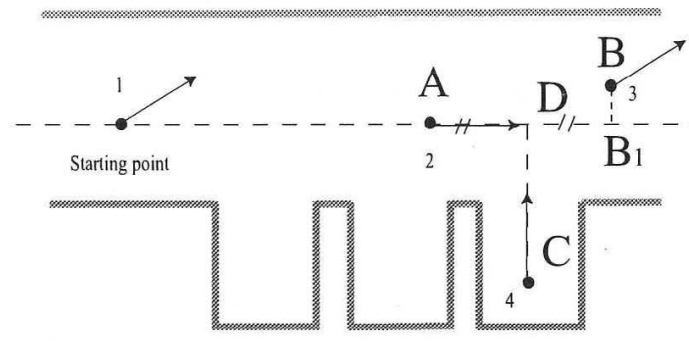

Fig. 6 Backward parking procedure

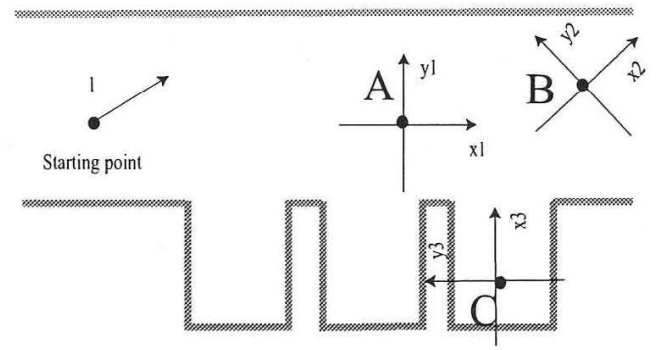

Fig. 7 Auxiliary coordinates

るとき，われわれはつぎの手順で行なう。まず，車両を駐車 スペースの近くへ移動させる。つぎに駐車スペースに入りや すい位置と方向へ移動して，そしてその状態から車両を駐車 スペースに入れる。以上の一連の操作を本制御則を用いてつ ぎのように実現する．Fig. 6 に示されるように 3 点 $A B C$ を選ぶ. 3 点 $A B C$ の位置の関係は駐車場の形に応じて柔 軟に変えればよい。ここでは，通路の中心線上に点 $A$ をと り, $A D=D B 1=2 B B 1=2 l / \eta_{\max }$ とする. Fig. 7 に示 されるように各座標系 $A(x 1, y 1), B(x 2, y 2), C(x 3, y 3)$ を 選ぶ. $x 1$ と $x 2$ のなす角度は $\pi / 4$ とする．前節で設計した 制御入力で各座標系 $A(x 1, y 1), B(x 2, y 2), C(x 3, y 3)$ に順 番に収束させればよい. 座標系 $A(x 1, y 1)$ から見たとき，初 期状態が条件 (39)，(40) を満たさない場合は Fig. 4 と同じ ように中間座標系 $B 1(x 3, y 3), A 1(x 1, y 1)$ 一収束させてか ら以上と同じ手順で行なう。

Fig. 8 はシミュレーションの結果を示す.シミュレーショ ンでは車両の長さを $1[m]$ とし，道路の幅を $2[m]$ とした。点 $C$ は駐車スペースの中心であり，点 $A, B$ の座標はそれぞれ 
$\left(x_{A}, y_{A}\right)=(-1[m], 1.5[m]),\left(x_{B}, y_{B}\right)=(1[m], 2[m])$ であ る. 車両の位置, 方向の初期值はそれぞれ $(x(0), y(0))=$ $(-4[m], 1.5[m]), \theta(0)=\pi / 4[\mathrm{rad}]$ である.

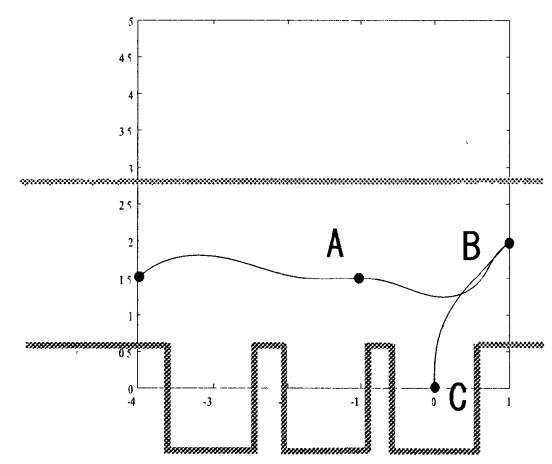

Fig. 8 Simulation result

後進駐車について制御実験を行なう際, ポジションセン サーの計測範囲が狭いので，車両を点 $\mathrm{A}$ からスタートさせ た.Fig. 9, Fig. 10 は実験結果を示す. Fig. 9 は車両の軌 道, Fig. 10 は操舵角を示している. 7 秒までに車両は $B$ 点 の座標系へ収束した。また 7 秒から 16 秒までの間に駐車 スペースへ移動した，スタートするときと目標座標を切り 替えるとき, 操舵角の飽和が起きている，また，各座標系の 原点に接近するときセンサー雑音の影響が大きくなるので, 操舵角が振動している.

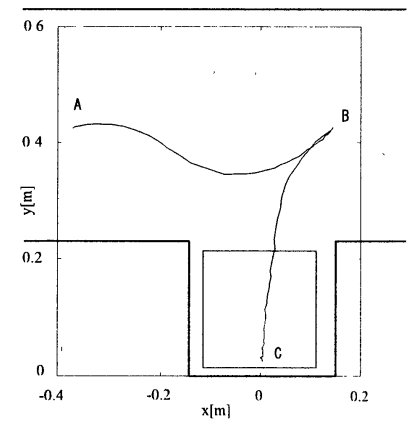

Fig. 9 Backward parking experiment $(x, y$ trajectory)

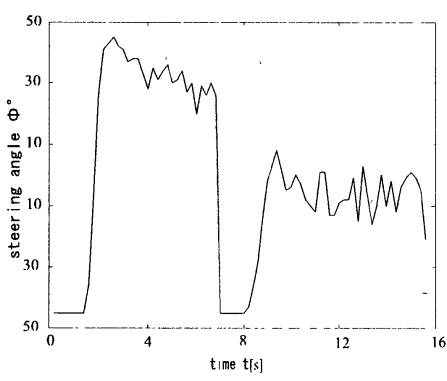

Fig. 10 Backward parking experiment(Steering angle $\phi$ )

\section{2 斜め駐車}

駐車しやすくするため，駐車スペースを斜めにする駐車場 もある. 駐車スペースを斜めにすることでFig. 11 に示すよ うに片方から入りやすくなるが，もう片方からは入りづらく なる. 本制御方法用いると斜め駐車も実現できる. Fig. 11 の ように通路の中心線上の駐車しやすい方に $A B=2 l / \eta_{\max }$ の点 $A$ を決める。 また, 各点 $A B$ に座標系 $A(x 1, y 1)$, $B(x 2, y 2)$ を決める. $x 2$ 方向は 駐車方向である. 車両を座 標系 $A(x 1, y 1), B(x 2, y 2)$ 一順番に収束させればよい。

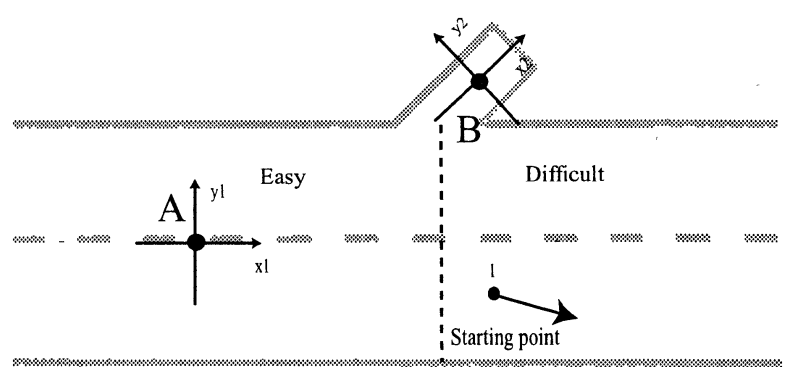

Fig. 11 Oblique parking

実験結果はFig. 12，Fig. 13 に示される.Fig. 12 は車両の 軌道を表わす．車両の状態が各座標系 $A(x 1, y 1), B(x 2, y 2)$ へ収束することがわかる。また，Fig. 13 は操舵角を表わす. ここでも目標座標を A から B に切り替えるとき, 操舵角が 飽和した。 バック駐車の場合と同様に各座標系 $A(x 1, y 1)$, $B(x 2, y 2)$ の原点に近づくとき操舵角が振動する.

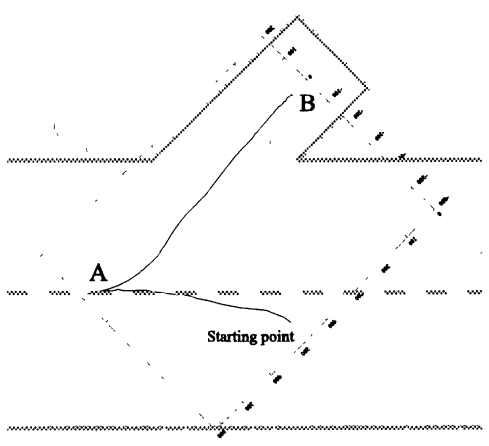

Fig. 12 Oblique parking experiment $(x, y$ trajectory) 


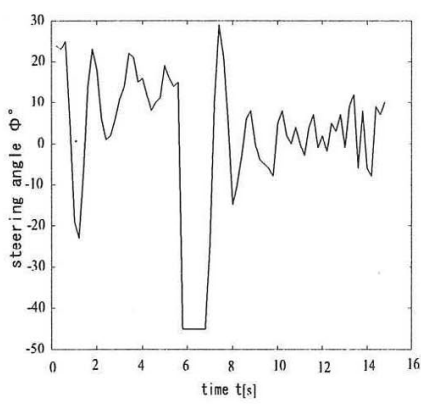

Fig. 13 Oblique parking experiment(Steering angle $\phi$ )

\section{3 駐車スペースから車両を取り出す}

ここでは実験を行なわなかったが，スタートするときの車 両の状態が決まっているので，バック駐車，斜め駐車よりも 簡単に実現できる.Fig.14は駐車位置から車両を取り出す 方法を示す.

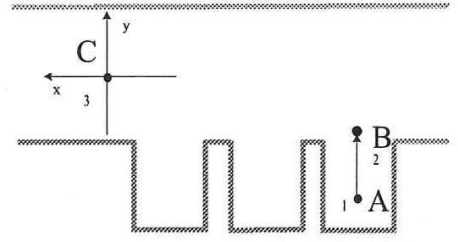

Fig. 14 Procedure for leaving the parking space

まず，取り出す車両が両側の車両に衝突しないように点 $B$ まで直進させる. 後は本制御側で通路の中心へ収束させ ればよい. Fig. 15 はシミュレーションの結果を示す.

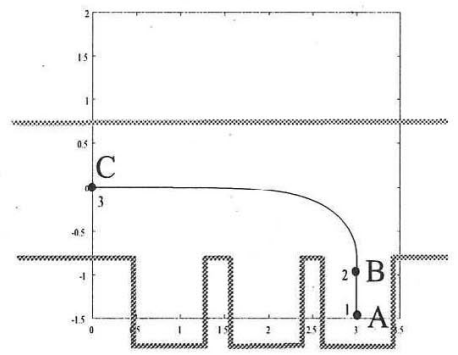

Fig. 15 Simulation result

\section{6. 結 論}

本論文では, 操舵角に制限をもつ 4 輪車の駐車問題に対 して比較的に簡単な制御則を提案した。この制御則を基本に してさまざまな駐車動作を実現できることを制御実験で示 した．制御手法の基本方策は駐車位置で駐車方向と接する円 軌道の接線方向を基準にして車両の方向を修正していくこ とである. また, 初期状態の情報から駐車可能かどうかを判
定できる条件も明らかにした。車両の状態が駐車位置に対し て入りにくい姿勢にあった場合は複数のステップに分けて， 各ステップで本制御則を用いれば駐車を実現できる。

\section{参 考 文 献}

1) R.W. Brockett: Asymptotic stability and feedback stabilization, in Differential Geometric Control Theory (R.W. Brockett, R.S. Millman and H.J. Sussmann Eds. Birkhauser), 181/191 (1983)

2）美多 勉: 非線形制御入門一劣駆動ロボットの技能制御論一, 昭晃堂 $(2000)$

3) A.Tayebi, M.Tadjine and A.Rachild: Invariant manifold approach for the stabilization of nonholonomic systems in chained form:Application to a Car-like mobile robot, Proceedings of 36th CDC, 4038/4043 (1997)

4) M.Reyhanoglu: On the stabilization of a class of nonholonomic systems usinginvariant manifold technique,Proceedings of 34th IEEE CDC,New Orleans, LA, 2125/2126 (1995)

5) J. Luo and P. Tsiotras: Exponetially convergent control laws for nonholonomic systems in power form, Systems 85 Control Letters, 35, 87/95 (1998)

6) K.Z. Liu and A. Kanehara: Steering control of vehicles by discontinuous control approach, Proc. of ACC'2001, $1521 / 1526$ (2001)

7）池田, 深谷, 美多：可変拘束制御による水中移動体の位置·姿 勢制御, 計測自動制御学会論文集, 37-11, 1026/1033 (2001)

8) C.Canudas de Wit and O.J.Sordalen: Exponential Stabilization of Mobile Robots with Nonholonomic Constraints, IEEE Trans. Automat. Control, 37, 1791/797 (1992)

9) S. Sastry : Nonlinear systems, p.530, Springer (1999)

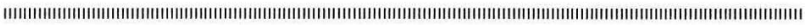

$$
\text { [著 者 紹 介] }
$$

Dao Minh QUAN (学生会員)

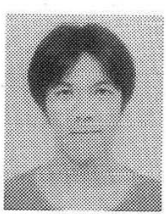

2000 年千葉大学工学部電子工学科卒業, 2002 年同大学自然科学研究科博士前期課程修了, 現在 同大学自然科学研究科人工システム科学専攻博士 後期課程に所属。

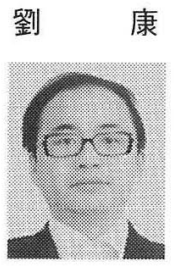

志 (正会員)

1984 年中国西北工業大学卒業, 91 年千葉大学 大学院学術博士, 96 年より一葉大学工学部助教 授。ロバスト制御, 適応制御, 非線形制御の研究 に従事. 著書「線形ロバスト制御」(コロナ社), 共 著「現代制御理論通論」(培風館)，共訳「ロバス 卜最適制御」(コロナ社).

大 形 明 弘 (正会員)

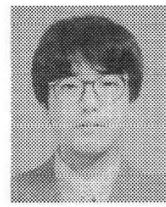

1999 年奈良先端科学技術大学院大学情報科学 研究科博士後期課程終了, 同年千葉大学工学部電 子機械工学科助手. 博士 (工学). システム制御情 報学会, IEEE などの会員. 